\title{
MATERIAEY
}

Matgorzata Ewa Kowalczyk

Instytut Historyczny,

Wydziat Nauk Historycznych i Pedagogicznych, Uniwersytet Wroctawski

\section{„Osobliwie muszę tu wyznać zrządzenie Boskie nad tobą Synu mój kochany, iż twoja najlepiej cię kochająca Matka, uniesiona często słabością rozumu swojego, bila cię i źle ci życzyła". Choroba psychiczna w rodzinie w drugiej połowie XVIII wieku na przykładzie dzieciństwa Stanisława Mikołaja Tretera}

\begin{abstract}
I must personally confess here, my dear son, to the cruel twist of fate that your most loving mother, frequently afflicted by weakness of mind, hit you and wished you ill". Mental disease in the family in the second half of the $18^{\text {th }} \mathrm{c}$. On the example of Stanisław Mikołaj Treter's childhood"
\end{abstract}

Stanisław Mikołaj, son of Agnieszka, nee Izbicki, and Stanisław Treter, the king’s chamberlain, was born on $19^{\text {th }}$ November 1776 . When he was seven years old it turned out that his mother was mentally ill, most probably suffering from schizophrenia. In the $18^{\text {th }}$ century mental and nervous disorders were very rare, and foreigners visiting Poland even thought they were characteristic of Poles. Certainly, mental disease in a family does not only affect the one who actually suffers from it, it has an impact on each family member and somehow everyone is involved.

Agnieszka's psychosis started with aggressive behaviour towards her family, and especially her son. She would destroy things which either belonged to him or were in some way related to him, she would scream at him, physically and mentally harass him. His father would usually buy the things the boy needed most, such as underwear, clothes and shoes, in well-kept secret. Agnieszka categorically opposed this and even "became stubborn and restless which influenced the atmosphere in this home". Because of his mother's disease and its influence on the atmosphere in the family, the boy often felt anxiety and fear, and sometimes even annoyance and despair.

In November 1786 Stanisław Treter decided that it would be better if his wife stayed in Warsaw for a while. The atmosphere at home was becoming worse and worse, and their ten-year-old son required systematic and extensive education, while Agnieszka herself needed "professional" care. In the $18^{\text {th }}$ century people who suffered from mental diseases would usually live with their families and be provided with good care and a kind of particular respect, unless they were dangerous to others. However, Agnieszka was completely unpredictable. Her irrepressible aggression was understood by her son as a lack of love and acceptance. He often felt lost and very lonely. His mother's mental disease did not create supportive conditions for the development of the child's emotions and 
mentality. Certainly, like any other child he loved his "Mummy" very much, so parting with her was a very difficult experience for the boy.

Disharmony in the Treter family, which was the consequence of Agnieszka's disease, developed in Stanisław Mikołaj patterns of instability, hostility and neglect. Thus it is not surprising that he became oversensitive, egoistic, combative and aggressive.

We learn about Stanisław Mikołaj Treter's difficult childhood from his father's notes. In 1785 he decided to write a history of his son's life and education, and it took him four years to write in 13 letters which are now kept in the Central State Historical Archive of Ukraine in Lvov.

Keywords: childhood, education, family, mental disease, $18^{\text {th }}$ century

Zaburzenia nerwowe i psychiczne w społeczeństwie polskim doby oświecenia nie należały do rzadkości. Cudzoziemcy odwiedzający Rzeczypospolitą w drugiej połowie XVIII w. widzieli w nich nawet charakterystyczne dla Polaków schorzenia. Francuz Hubert Vautrin uważał wręcz, że Polacy częściej zapadaja na choroby głowy niż innych organów ${ }^{1}$. Najwięcej tego rodzaju spostrzeżeń kierowano pod adresem szlachty. Wiele schorzeń nerwowych i psychicznych, na które cierpieli jej przedstawiciele, było skutkiem kiły - rozpowszechnionej w wyniku swobody obyczajów, alkoholizmu i obciążeń dziedzicznych - potęgowanych przez małżeństwa krewniacze. Pojawienie się różnorodnych zaburzeń miało też związek z długotrwałym stresem, wysokim poziomem lęku oraz obciążającymi przeżyciami życiowymi, np. rozłąką lub śmiercią bliskiej osoby, kłopotami finansowymi².

Zaburzenia psychiczne jednej z osób w rodzinie dotyczą nie tylko samego chorego, ale obejmują każdego domownika, sprawiając, że wszyscy są wciągnięci w chorobę. Rodzina nie jest bowiem jedynie zbiorem niezależnie funkcjonujących od siebie jednostek. Członkowie rodziny oddziałują na siebie i każda osoba - jej zachowanie, samopoczucie, zależy od wszystkich pozostałych. Tak więc, zachowanie dziecka pozostaje pod różnymi wpływami rodziców, ale jednocześnie oddziałuje na ich zachowanie. Ponadto pozostaje pod wpływem relacji pomiędzy matką a ojcem, a to z kolei oddziałuje na istotę działań rodzicielskich. Nagłe pojawienie się choroby psychicznej u jednego z rodziców staje się więc silnym źródłem stresu dla reszty członków rodziny i nie pozostaje bez wpływu na ich wzajemne relacje, a nawet może zachwiać równowagę panującą w całej rodzinie ${ }^{3}$. Nierzadko bowiem konsekwencją zaburzeń psychicznych jest upośledzenie zdolności chorego do harmonijnego współżycia z otoczeniem, wykonywania obowiązków domowych, zapewnienia dziecku wszechstronnego rozwoju fizycznego, duchowego, intelektualnego, a przede wszystkim psychicznego. Chory rodzic często nie zaspokaja podstawowych psychicznych potrzeba dziecka, takich jak: potrzeba bezpieczeństwa, miłości, akceptacji, szacunku, uznania. Tak więc szczęśliwe dzieciństwo może skończyć się

${ }^{1}$ H. Vautrin, Obserwator w Polsce, w: Polska stanisławowska w oczach cudzoziemców, oprac. W. Zawadzki, Warszawa 1963, s. 820.

${ }^{2}$ B. Popiołek, Kobiecy świat w czasach Augusta II. Studia nad mentalnościa kobiet z kręgów szlacheckich, Kraków 2003, s. 172-175; Z. Kuchowicz, Człowiek polskiego baroku, Łódź 1992, s. 97-100.

${ }^{3}$ H. R. Schaffer, Psychologia dziecka, Warszawa 2005, s. 109-115. 
niemal natychmiast, z chwilą ujawnienia się u jednego z rodziców zaburzeń psychicznych.

Tak było w przypadku Stanisława Mikołaja Tretera (1776-1861). W 1783 r., kiedy miał siedem lat, u jego matki - Agnieszki z Izbickich (1746 - ok. 1827), ujawniła się choroba psychiczna, prawdopodobnie schizofrenia. O trudnym dzieciństwie Stasia dowiadujemy się z notatek jego ojca - Stanisława Tretera (1744-1833), szambelana królewskiego, który w 1785 r. podjął decyzję spisania historii życia i edukacji swojego potomka. Opracowanie dziejów młodych lat życia syna zajęło Treterowi cztery lata i zawarte zostało w trzynastu listach. Jeden list to historia jednego roku życia i edukacji Stanisława Mikołaja ${ }^{4}$. Kiedy w listopadzie 1789 r., czternastoletni chłopiec sam zaczął pisać dziennik, już na wstępie zaznaczył: Zaczątem od dnia 19 tego miesiaca i roku bieg życia mojego opisywać. Do czasu zaś tego, zaczawszy od mego urodzenia, Ociec mój najukochańszy całe moje życie i cała edukacja zawart i ręka swoją opisat w listach 13 do mnie obróconych, które się w osobnej książe pieczęcia Ojca mojego zamkniętej w schowaniu u mnie znajdują, z tym wyraźnym Ojca mojego rozkazem, abym tej ksiażki bez pozwolenia ojcowskiego nie odpieczentywywat i nie czytat5. O dramacie rodziny wiele dowiadujemy się również z dzienników, notatek i autobiograficznych zapisków Stanisława Tretera ${ }^{6}$. Ów bogaty materiał źródłowy jest przechowywany obecnie w Centralnym Państwowym Archiwum Historycznym Ukrainy we Lwowie.

Stanisław Mikołaj Treter urodził się 19 XI 1776 r. w Paryżu. Kiedy wiosną 1775 r. jego rodzice opuszczali Polskę, by w kompanii Anny Teresy z Ossolińskich Potockiej (1746-1810), krajczyny wielkiej koronnej, odbyć podroż po Europie, nie byli małżeństwem. Nie przypuszczali nawet, że w trakcie pobytu za granicą pobiorą się i urodzi im się $\operatorname{syn}^{7}$.

Agnieszka i Stanisław poznali się w Warszawie w kwietniu 1771 r. W ciągu kilku lat ich znajomość przerodziła się w miłość, którą pragnęli usankcjonować małżeństwem. Kiedy jednak w styczniu 1775 r. Stanisław wyjawił ojcu - Mikołajowi Treterowi, pisarzowi ziemi stężyckiej, swoje matrymonialne plany, spotkał się z jego kategorycznym sprzeciwem. Gdy ta rodzicielowi memu mniej majętna partia - wyznał Stanisław na kartach dziennika - nie zdaje się być dla mnie przyzwoita, jestem mu postusznym oczekując z zmartwieniem dalszego zrządzenia opatrzności Boskiej nade mna. Co większa z powodu winnego postuszeństwa Ojcu mojemu, idę szukać tej dla mnie przyjaciółki, która mi nie rozum, ani serce, ani sumienie i obranie moje, lecz wola jego i rada skazu-

${ }^{4}$ M. E. Kowalczyk, , Synu mój najmilszy...”. Życie i edukacja Stanisława Mikołaja z Lubomirskich Tretera $w$ latach 1776-1789 opisane przez ojca $w$ trzynastu listach [w druku].

${ }^{5}$ CPAHUL, Zespół 836, opis 1, sygn. 1043, Stanisław Mikołaj z Lubomirskich Treter, Dziennik życia mego 1789-1794, k. 2.

${ }^{6}$ Autorka artykułu opracowuje do druku część rękopisów Stanisława Tretera oraz przygotowuje do publikacji biografię Stanisława i Agnieszki z Izbickich Treterów.

${ }^{7}$ M. E. Kowalczyk, ,, W kompanii podróżnej krajczyny koronnej Anny Teresy Potockiej”. Zapiski z wojażu po Europie Stanisława i Agnieszki z Izbickich Treterów, w: Samotrzeć, w kompanii czy z orszakiem? Społeczne aspekty podróżowania w średniowieczu i czasach nowożytnych, red. M. Saczyńska, E. Wółkiewicz [w druku]. 
$j e^{8}$. Zakochana w Stanisławie Agnieszka, aby nie dopuścić do jego małżeństwa z inną kobietą, wykazała się ogromną pomysłowością. Będąc ,mniej majętną” panną pozostawała na dworze Potockiej jako jej dama do towarzystwa, i w takiej też roli miała wyjechać z karajczyną za granicę. Wtajemniczając swoją dobrodziejkę w perypetie związane z usankcjonowaniem wieloletniej przyjaźni z Treterem, przekonała ją o konieczności zabrania ukochanego za granicę. Potocka godząc się na to, przewidziała dla Stanisława rolę logistyka jej peregrynanckiego przedsięwzięcia. Nadawał się do tego wybornie. Był świetnie wykształcony, poznał już skrawek Europy, studiując w latach 1767-1771 na Akademii Lipskiej, władał biegle kilkoma językami, dodatkowo zaś wybornie grał na skrzypcach i był literacko uzdolniony. Nic zatem dziwnego, że krajczyna dołożyła starań, aby Treter znalazł się w jej kompanii. Jak przyznał sam zainteresowany: To dobrodziejstwo winienem przypisać kochanej mojej przyjaciótce. Chętnym sercem do tej przysposabiam się podroży, która zdarza mi do pożycia codziennego z tąż najżyczliwsza przyjaciótka i do poratowania zdrowia okazją . Ów ostatni argument był koronnym w rozmowach z ojcem, który ostro sprzeciwiał się wyjazdowi syna. Zdesperowany Stanisław przedstawił mu więc opinie doktorskie i recepty na ratunek zdrowia, których werdykt brzmiał: użycie wód potrzebne ${ }^{10}$. Oczywiście wyjazd krajczyny, która miała w planach pobyt u wód akwizgrańskich oraz spaskich, był niejako doskonałą okazją do zabrania się w jej kompanii.

W podróż wyruszono 18 V 1775 r. z Warszawy. Szlak wiódł przez Kutno, Wrześnię, Poznań i Międzyrzecz do Berlina, a stamtąd przez Poczdam, Lipsk, Erfurt, Frankfurt nad Menem i Kolonię do Akwizgranu, a następnie do Spa. W słynnym z leczniczych gorących źródeł uzdrowisku bawiono dwa miesiące. Ze Spa udano się do Metz, później do Lunéville, Bazylei, Lozanny, Genewy i wreszcie do Paryża, gdzie pod koniec 1775 r. dotarła do Stanisława Tretera wiadomość o śmierci ojca. Ta smutna informacja była na swój sposób pomyślna dla niespełnionych kochanków. 1 I 1776 r. Stanisław podarował Agnieszce zaręczynowy pierścionek, a 13 II 1776 r. ożenił się z nią ${ }^{11}$. Jeszcze w tym samym roku przyszedł na świat Stanisław Mikołaj.

W kwietniu 1777 r. Treterowie rozpoczęli przygotowania do powrotu do Polski. Paryż opuścili 6 czerwcu, udając się przez Lunéville, Strasburg, Augsburg i Monachium do Wiednia, gdzie dotarli 21 czerwca. Dwa dni później Stanisław opuścił stolicę Austrii, spiesząc „do interessów domowych”, a Agnieszka i siedmiomiesięczny Staś pozostali W mieście, czekając na przyjazd Anny Teresy Potockiej, a następnie na jej decyzję powrotu do kraju. Do Wiednia Potocka dotarła 25 czerwca. Agnieszka pragnęła jak najszybciej powrócić do kraju i znaleźć się wraz z synkiem u boku męża. W Wiedniu przy-

${ }^{8}$ CPAHUL, Zespół 836, opis 1, sygn. 823, Ciag dalszy biografii Stanisława II z Lubom. Tretera pod. nadw. Stan. Aug. król. pols. oraz Agnieszki z Izbickich jego matżonki od dnia 1 stycz. R.P. 1770 ciagniącej się. Książka III, k. 176.

${ }^{9}$ Ibidem, k. 178.

${ }^{10}$ Ibidem, k. 176 v.-181.

${ }^{11}$ CPAHUL, Zespół 836, opis 1, sygn. 741, Odpis metryki ślubnej Stanisława i Agnieszki z Izbickich Treterów. 
szło jej jednak spędzić dwa miesiące. W tym czasie Stanisław Treter przygotowywał dworek w Burzcu - zaniedbany przez długie miesiące nieobecności gospodarza w kraju - na przyjazd rodziny, który nastąpił 21 września. W zapiskach Stanisława Tretera z lipca czytamy: Prawie opuszczony od wszystkich, sam jeden otoczony zewsząd niepomyślnemi interessami, bez ludzi służacych, bez żony i innych nauczonych wygód i potrzeb, od kilku dni siedzę w Burzcu i jak moge z cierpliwościa radzę sobie i interessom, koło wszystkiego sam najwięcej pracując i przemyśliwając o dalszym z żona i dziećmi, jeżeli ich Pan Bóg da więcej, pożyciu ${ }^{12}$.

Agnieszka i Stanisław Treterowie mieli jeszcze trójkę dzieci: Teresę urodzoną 17 III 1780 i zmarłą 26 VIII 1781 r., Petronelę Mariannę urodzoną 1 VII 1781 i zmarłą 25 IX 1782 r. oraz Bonawenturę, który urodził się 13 VII 1782 i zmarł 15 VIII 1783 r. $^{13}$ To pasmo tragedii odbiło się na zdrowiu Agnieszki. Cztery miesiące po śmierci ostatniego dziecka ujawniła się u niej choroba psychiczna. Przebywała wówczas wraz z siedmioletnim Stasiem w Tarnowcu. W Liście ósmym zawierajacy życie Stanisława Mikołaja ... Stanisław Treter zapisał: Dla słabości jej zmystów zaniedbany, cudem Opatrzności Boskiej uchowany byłeś od przypadków i niebezpieczeństw, w których się tam nieszczéśliwa znajdowała Matka twoja, z która w miesiacu grudniu przeniosłeś się do Lwowa, lecz $i$ tam równie, aż do mego przyjazdu, potrzebnego koło siebie, tak co do potrzeb twoich, jako $i$ wychowania, nie mogłeś mieć starania ${ }^{14}$. Stanisław Treter po odebraniu 22 grudnia najfatalniejszej nowiny o obłąkaniu zmysłów żony natychmiast pospieszył do Tarnowca. Czynione przez niego w drodze telegraficzne zapiski oddają dramat całej sytuacji. Dnia tego odstapienie wszystkich interessów. Wyjazd najpilniejszy do Tarnowca. Smutek największy. Nocleg w Czemiernikach. D[nia] 23 popas w Lewartowie. Nocleg w Lublinie. Troski najżwsze. D[nia] 24 popas w Bychawce. Drugi w Wysokim. Wystanie stąd [umyślnego - M.E.K] do Tarnowca. Spoczynek w Otroczu. D[nia] 25 droga nocna. Bład po śniegach. Pieszo zaledwie wyszukanie drogi. Utrudzenie wielkie. Popas w Frampolu. Dzienna i nocna jazda. Popas w Bitgoraju. Dalszy zapęd do Tarnowca. Spotkanie wystańca z wiadomościa o żonie mojej w Różańcu. Zwrot do Biłgoraja, do Różańca. Trudne przebycie komory cesar[skiej] w Majdanie. Awantura z[e] strażnikiem równie złym jako i pies jego. Przybycie do Różańca. Tu wiadomość o żonie i dziecku, że sa w Lwowie. D[nia] 26 z Różanki mil 14 ujechałem. Przybycie w nocy do Lwowa. Zastanie tamże najlepiej ulokowana żonę. Protekcyja wielka nad nia JPani Tere[sy] Potocki $k[$ rajczyny] $w$ [wielkiej] $k$ [oronnej]. Nadzieja o przywrocie zdrowia żony. D[nia] 27 bawiłem

12 CPAHUL, Zespół 836, opis 1, sygn. 824, Ciag dalszy biografii Stanisława II z Lubom. Tretera pod. nadw. Stan. Aug. król. pols. oraz Agnieszki z Izbickich jego matżonki od dnia 1 stycz. R. P. 1776 ciagniącej się. Książka IV, k. 21 v.-22.

${ }_{13}$ CPAHUL, Zespół 836, opis 1, sygn. 729, Zbiór życia zdarzeń Stanisława II z Lubom. Tretera ręka jego pisanych. Część I, II, III. Do roku 1800, k. 135-176.

${ }^{14}$ CPAHUL, Zespół 836, opis 1, sygn. 1042, Stanisław z Lubomirskich Treter, List ósmy zawierajacy życie Stanisława Mikołaja z Lubomirskich Tretera od d. 19 listopada 1783 roku do d. 19 listop. r. 1784, Mikołajów 20 XI 1789, k. 43-43v. 
przy żonie mojej. Smutne moje przeczucia uwagi! D[nia] 28 wystanie do Tarnowca po rzeczy. Zakończenie miesiaca i roku w Lwowie. Okropne myśli o złej sytuacji ${ }^{15}$.

Psychoza Agnieszki zaczęła się od wrogich zachowań wobec męża. Żona moja, która mnie zawsze najlepiej kochała - zapisał w dzienniku Stanisław Treter - moca słabości swojej teraźniejszej uniesiona, dusza cała okazuje się mnie nienawidzić, a co większa, najwierniejsza dla mnie zawsze będac, teraz sposobem niewinnym, gdyż słaba na zmysłach, szuka z innemi mężczyznami przyjaźni i miłości, i za nia tęsknić się zdaje ${ }^{16}$. Na żądanie Agnieszki 4 I 1784 r. Stanisław wyjechał ze Lwowa. Nie pozwoliła mu jednak zabrać ze sobą syna.

Treter zanim wrócił do Burzca, pojechał do Tarnowca, aby na miejscu dowiedzieć się, w jakich okolicznościach ujawniła się u Agnieszki choroba. Warto zacytować jego ustalenia: Dzień 7 czyli 8 grudnia byt poczatkiem nieszczęśliwym jej pomieszania w Leżajsku u Państwa Kẹpińskich, a bardziej stamtąd powróciwszy, bezsennościa i myślami dziwnemi osłabiona na rozumie, niepojęta bojaźnia zawsze zostawała napetniona, zamykała się, oknem tylko z ludźmi rozmawiając, paliła rzeczy swoje, uciekała $w$ dzień $i$ w nocy z mieszkania swojego, i inne tym podobne, słabość jej głowy okazujące, petniła pomieszania, $w$ których ludzkiej żadnej prawie rozumnej w początkach swej melancholii nie majac pomocy. Boska tylko opatrznościa sama i z dziecięciem Stasiem ratowana i broniona od śmierci została, osobliwie w tym razie, gdy przebrawszy się w nocy w koszule i sukmanne chłopska w czasie największego śniegu i mrozu do Różańca o mil 4 od Tarnowca uszła (cudem Boskim, że bez dziecięcia), w tej drodze nogę i rękę odmroziła, u popa tamtejszego dni kilka w najmizerniejszym stanie siedziała, stamtąd listem swoim do Bychawki pisanym o swym nieszczęściu doniosła i sama się do Lwowa z trudnościa, cudem, że bez nieszczęścia, wieść kazała, gdzie teraz w rękach największej dobrodziejki będąc JP Potocki, daleko się lepiej ma. Nogi i ręce uleczone przez wybornego felczera P. Jastrzębskiego, wewnętrzna zaś jej słabość ciała i głowy, sławny we Lwowie doktor JP Spawenti pomyślnie i pilnie liczy ${ }^{17}$.

Jeszcze pod koniec stycznia Stanisław zdecydował się pojechać do Lwowa, by zobaczyć żonę i synka. Agnieszka z przyjazdu męża była bardzo niezadowolona, wykrzyczała mu nawet, że go nienawidzi, że nie chce mieć z nim nic wspólnego, i że każdy inny mężczyzna byłby jej milszy niż on. Absolutnie nie dopuszczała myśli, by powrócić do domu, nie chciała też słyszeć o tym, by mąż zabrał ze sobą syna. Krajczyna wielka koronna Anna Teresa Potocka obiecała Treterowi zająć się Agnieszką i Stasiem, zwłaszcza jego edukacją. 13 lutego Treter wyjechał z Lwowa prawie z płaczem rozstawszy się z biedna żona $i$ dziecięciem ${ }^{18}$. Udał się do Halicza, gdzie mieszkała jego teściowa, aby

${ }^{15}$ CPAHUL, Zespół 836, opis 1, sygn.729, Zbiór życia zdarzeń Stanisława II z Lubomir. Tretera ręka jego pisanych..., k. 179v-181.

${ }^{16}$ CPAHUL, Zespół 836, opis 1, sygn. 732. Ciąg dalszy biografii Stanisława II z Lubomri. Tretera pod. nad. Stan. Aug. król. pols. oraz Agnieszki z Izbickich jego matżonki od dnia 1 stycz. R. P. 1780 ciagniącej się. Książka V, k. 79v.

17 Ibidem, k. 81-82.

${ }^{18}$ Ibidem, k. 86v. 
prosić ją o pomoc w opiece nad Agnieszką i Stasiem. Katarzyna Horodyńska, primo voto Izbicka, secundo voto Kobylska, nie odmówiła pomocy i wraz z zięciem przyjechała 20 lutego do Lwowa, aby zamieszkać przy córce i wnuczku. 14 marca Stanisław wyjechał do Burzca, gdzie stanął po sześciu dniach drogi.

W kolejną podroż do żony i synka wybrał się 10 maja. Tym razem udało mu się przekonać żonę, by wróciła z nim i Stasiem do domu. O podróży tej zapisze w dzienniku: Znoszę jak najcierpliwiej jej słabości i niecierpliwości, obawiając się, aby chęci swojej do powrócenia nazad do Lwowa do skutku nie przywiodła. [...] Stabość rozumu żony mojej niewymownie i często bardzo duszę moją przeraża ${ }^{19}$.

Treterowie dotarli do Burzca 15 czerwca. Spokojne życie w dworku wywróciło się do góry nogami. Jak zapisał w dzienniku Treter, choroba Agnieszki wielka i nieopisana sprawiła ruine $w$ majątku naszym ruchomym, a nawet $i$ teraz, gdy jej momenta niecierpliwości i pomieszania przyjda, ciska, tlucze i najpiękniejsze, i najdroższe naczynia, rze$c z y^{20}$. Agnieszka, kiedy wpadała w furię, biła nawet męża, aż do znaku w skórze - jak sam otwarcie przyznał ${ }^{21}$. W listopadzie 1784 r. próbowała zrobić sobie krzywdę, być może nawet popełnić samobójstwo.

Ośmioletni Staś - pod wpływem choroby psychicznej matki oraz atmosfery panującej w domu - żył w permanentnym strachu. Najgorsze było to, że matka, choć bezgranicznie go kochająca, stanowiła dla niego zagrożenie. Wiedz o tym Synu mój, iż z rządzenia Stwórcy świata - pisał w Liście... do niego ojciec - mimo wielkie przywiazanie twojej najukochańszej Matki do ciebie zawsze w niebezpiecznych i nieszczęśliwych z jej przyczyny zostawałeś okolicznościach. Ta biedna Matka twoja uchybiając częstokroć zdrowego rozumu w punktach edukacyi i utrzymania zdrowia twego, a sto razy pasja gniewu uwiedziona zostawszy, niepomiarkowanie cię uderzała. Lecz ja ile możności strzegłem cię i pilnowatem ${ }^{22}$.

Stanisław Treter obawiając się o zdrowie, a nawet życie syna, nie rozstawał się z nim, zabierając go zawsze ze sobą, kiedy interesy i obowiązki służbowe zmuszały go do wyjazdu z domu. Częstokroć podróż musiała być przedsięwzięta w największej tajemnicy, aby wyjazd syna nie rozgniewat $i$ nie turbowat matki. W tajemnicy przed nią musiano też kupować Stasiowi niezbędne rzeczy: bieliznę, ubrania, buty. Agnieszka kategorycznie sprzeciwiała się nabywaniu nowych rzeczy dla dziecka, aż do uporu i niespokojności, która się stąd $w$ domu rozniecała. Nowa garderoba chłopca zawsze musiała być dobrze schowana. Ojciec przebierał w nią syna - rzecz jasna nie na oczach matki - kiedy jechali do kościoła, w gości lub udawali się w podróż. W domu zaś częstokroć - zapisał Stanisław Treter - nosiłeś się i przybierałeś podług widzimisię $i$ woli Matki twojej, $i$ bywało to, że najśmieszniejszy i najgorszy ubiór twemu dziecinnemu i jej słabemu rozumowi podobat się. Ja tylko kochany Synu mój czułem stąd prawdziwe zmartwienie ${ }^{23}$.

\footnotetext{
19 Ibidem, k. 99v-100v.

20 Ibidem, k. 101v-102.

21 Ibidem, k. 104.

22 CPAHUL, Zespół 836, opis 1, sygn. 1042, Stanisław z Lubomirskich Treter, List ósmy..., k. 44-44 v.

${ }^{23}$ Ibidem, k. 59-59 v.
} 
Najbardziej przerażała nieuzasadniona wobec Stasia agresja Agnieszki. Mając świadomość, że w synu narastało poczucie winy, ojciec zapewniał go: Twoja najlepiej cię kochająca Matka, uniesiona często słabościa rozumu swojego, biła cię $i$ źle ci życzyła, co bynajmniej zasmucać cię i przerażać nie powinno z ciagnienia stąd niebłogostwa jej skutków, gdyś na nie nigdy (czczac zawsze i szanując twych Rodziców) nie zastużyłeś24.

Choroba Agnieszki negatywnie odbijała się nie tylko na życiu rodzinnym i panującej w domu atmosferze, ale również na edukacji syna. W Liście dziewiatym... przeczytać możemy: Słabość rozumu Matki twojej przywiodła ja (jako to robi częstokroć) do przeszkody $w$ postępowaniu z toba $i$ doskonalenia cię $w$ edukacyi $i^{25}$. Agnieszka niszczyła książki Stasia, darła w strzępy zeszyty z jego kaligrafią, wyrywała z kajetów teksty pieśni, których się uczył. Dzieci potrzebują korzystnej atmosfery domowej przez całe swoje dzieciństwo, ale jest to szczególnie ważne podczas lat edukacji ${ }^{26}$. Pozytywna atmosfera domowego ogniska zwykle niesie ze sobą konsekwentnie stosowaną dyscyplinę i zachętę do nabywania przez dziecko społecznych i emocjonalnych kompetencji. Zdrowe formy rozwoju dziecka zależą również od stopnia, w jakim rodzice próbują zaspokoić jego potrzeby. Jeśli dziecko nie otrzymuje tego, to jest emocjonalnie niestabilne, niewspółpracujące, a przede wszystkim nieszczęśliwe ${ }^{27}$.

W grudniu 1786 r. Stanisław Treter podjął decyzję ulokowania Agnieszki na jakiś czas w Warszawie, przy Szpitalu Św. Ducha, zostawując dozór nad jej krokami temuż Szpitalowi ${ }^{28}$. Atmosfera w domu stawała bowiem coraz cięższa, ich dziesięcioletni syn wymagał systematycznej i poszerzonej edukacji, sama zaś Agnieszka „fachowej” opieki. W XVIII w. chory psychiczne dopóki nie stawał się niebezpieczny, żył w rodzinie, otoczony troskliwą opieką i pełnym lęku swoistym poszanowaniem ${ }^{29}$. Agnieszka była jednak nieobliczalna. Miałeś już tyle rozeznania Synu mój - zapisał Stanisław Treter - żeś o celu smutnej tej podróży naszej do Warszawy wiedziat, to jest żeśmy ja przedsięwzięli dla ulokowania tam biednej i stabej Matki twojej, jednak często ze mna samym o tym smutnym rozstaniu się rozmawiając, przed nia, ani przed nikiem potrzebnego nie wydałeś dekretu $^{30}$. Ojciec własnym przykładem uczył syna ogromnego szacunku do chorej matki. Często powtarzał mu, że kocha go ona najbardziej na świecie. I mimo że Agnieszka niejednokrotnie podnosiła na Stasia rękę i złorzeczyła mu, on kochał ją mocno. Dzieci maltretowane mimo wszystko zdradzają oznaki przywiązania do agresywnego rodzica, chociaż często okazują to w sposób mało wyraźny. Przywiązanie często jest tak silne, że

${ }^{24}$ Ibidem, List dziewiaty..., k. 48.

${ }^{25}$ Ibidem, k. 48-48 v.

26 D. Żołądź-Strzelczyk, Dziecko w dawnej Polsce, Poznań 2002, s. 195-229.

27 J. S. Turner, D. B. Helms, Rozwój człowieka, Warszawa 1999, s. 316.

${ }^{28}$ CPAHUL, Zespół 836, opis 1, sygn. 733. Ciag dalszy biografii Stanisława II z Lubom. Tretera pod. nad. Stan. Aug. król. pols. oraz Agnieszki z Izbickich jego matżonki od dnia 1 stycz. R. P. 1785 ciagniacej się. Książka VI, k. 32.

29 W. A. Brodniak, Choroba psychiczna w świadomości społecznej, Warszawa 2000, s. 99; F. Lebrun, Jak dawniej leczono. Lekarze, święci i czarodzieje w XVII i XVIII wieku, Warszawa 1997, s. 143-145.

${ }^{30}$ CPAHUL, Zespół 836, opis 1, sygn. 1042, Stanisław z Lubomirskich Treter, List dziesiąty..., k. 57 v.-58. 
nawet w obliczu agresji i braku ciepła emocjonalnego, dzieci dążą do związania się z rodzicem ${ }^{31}$. Rozstanie z „Mamunią” było więc bardzo trudne. Niełatwo było też Stanisławowi Treterowi. Po powrocie do domu 29 grudnia zapisał w dzienniku: smutniejsze mi się teraz wydaja katy, równie jak we wdowiałym stanie bez kochanej żony mojej, ta jest mi zawsze na myśli i sercu. Targany wyrzutami sumienia z powodu umieszczenia żony w Warszawie, wypisał w dzienniku główne przyczyny, które go do tego zmusiły:

1. Ratunek jej własnego zdrowia, którego tu na wsi nigdy mieć nie mogła.

2. Bezpieczeństwo zdrowia naszego dziecięcia, które podlegało jej pasyi, jej zdaniom i praktykom przeciwnym rozumowi.

3. Utrzymanie edukacji tegoż dziecięcia, które dla złego przykładu, dla jej przeciwieństwa i mieszania się $w$ nia, wielkie $w$ niej miało przeszkody.

4. Dla jej własnej rozrywki, którą snadniejszym sposobem mieć będzie w Warszawie, jak na wsi.

5. Dla utrzymania mego własnego zdrowia, na umniejszeniu którego (arcyniestałemi postępkami lubo niewinna dążyła) nikt większej zawziętości doznawać nie mógt jak ja, nikt więcej ponosić codziennie obelg najbrzydszych jak ja, a częstokroć unosita się do zadawania mi ran i guzów, pociskajac za mną instrumenta, który by się stać mogli okazja kalictwa lub śmierci mojej.

6. Dla ulzenia i zachowania honoru domu; utrzymać jej nie można byto, aby się byle razy na uragowisko ludzkie, po różnych miejscach, czasem boso, w stroju niezwyczajnym, piechotując czasem po największym błocie mil 2 lub 3.

7. Dla utrzymania przy spokojności różnych interesów i gospodarstwa, w których ona zawsze robiac podług jej głowy wszystko, ludzi brać i rozganiać, przewracała.

8. Chroniąc się na ostatek (pominawszy niezliczone przeszłe szkody) innych nieustających, które sobie, mnie i jedynemu naszemu dziecięciu czyniła zawsze $w$ domu, palac, drac, prując, łamiąc różne odzienia, bielizny, sprzęty, a co większa ognie, głównie zapalone po katach roznoszac.

Te to więc smutne okoliczności, w których ja się już blisko dwóch lat znajdowatem, przyniewolity mnie nieszczęśliwego zawsze, zbyt słaba na rozumie oddalić od siebie $i$ dziecięcia naszego, nieoszacowana niegdyś żonę $e^{32}$.

Współczesne badania psychologiczne dowodzą, że choroba psychiczna jednego z rodziców ma ogromny destrukcyjny wpływ na rozwój dziecka. Gdy bliski w rodzinie traci równowagę psychiczną, dziecko odczuwa niepokój, czasem irytację i rozpacz. Jeśli w dodatku jest maltretowane, rodzi to w dziecku strach, nieufność i reakcje nerwicowe. Pierwiastek strachu jest dodatkowo wzmacniany, kiedy przemoc cechuje stosunki między rodzicami. Dziecko maltretowane staje się agresywne, wycofujące, pełne niechęci. Niewłaściwe traktowanie we wczesnym wieku prowadzi do psychopatologii w wieku późniejszym ${ }^{33}$.

\footnotetext{
31 H. R. Schaffer, op. cit., s. 131.

32 CPAHUL, Zespół 836, opis 1, sygn. 733. Ciag dalszy biografii..., k. 33v-34v.

33 H. R. Schaffer, op. cit., s. 131.
} 
Dysharmonia w rodzinie Treterów spowodowana chorobą Agnieszki, dała Stasiowi wzory niestałości, wrogości, odrzucenia. Lęk wzbudzony przez agresywną matkę i wynikający z tego brak ufności, jak nic innego odarły go z poczucia bezpieczeństwa i utrudniły mu wypracowanie umiejętności społecznych, potrzebnych do nawiązania późniejszych kontaktów. Stanisław Mikołaj wyrósł na człowieka przewrażliwionego, egoistycznego, niestałego, konfliktowego i agresywnego. 